\title{
Teaching Soldiers French: How Motivation Affects Their Success
}

\author{
Marie KALA and Magdalena VESELA
}

University of Defence, Brno, Czech Republic

Correspondence should be adressed to: Marie KALA; marie.kala@unob.cz

Received date:24 March 2021; Accepted date:2 August 2021; Published date: 8 October 2021

Academic Editor: Ayoub Nefzi

Copyright (c) 2021. Marie KALA and Magdalena VESELA. Distributed under Creative Commons Attribution 4.0International CC-BY 4.0

\begin{abstract}
The paper deals with problematic of teaching adults a second foreign language. The article has focused on the groups of young soldiers who attended French courses for a period of two to four weeks during the fall semester of 2020 in the COVID pandemic situation. The main objective of the paper is to help teachers better plan teaching for specific groups of students. In this paper, the motivation of course participants have been examined. The paper suggests that the intrinsic motivation of the students allows participants to learn the language better. It has been observed that neither previous education in French nor career development is significant for student success. The findings suggest that students who were intrinsically motivated before the start of the course (for personal or professional reasons) tended to work more in their free time; and therefore, they mastered French sooner. The findings helped the researchers gain a better understanding of student failure and helped them in the adaptation of offered courses. The paper could be useful for anyone teaching adults a second language.
\end{abstract}

Keywords: French, Language Teaching, Intrinsic Motivation

\section{Introduction}

The Institute of Language Centre is a part of The University of Defense and provides French courses for soldiers deployed abroad, in our case to Mali. Most of the students were not exposed to the French language before. They undergo French intensive courses planned for either two, three, or four weeks and it is an integrated part of their mission preparation. At the same time, the university offers ten-week courses, which result in the Stanag exam (the level corresponds to A2 on CEFR level).

Cite this Article as: Marie KALA and Magdalena VESELA (2021)," Teaching Soldiers French: How Motivation Affects Their Success “, Journal of Human Resources Management Research, Vol. 2021 (2021), Article ID 865905, DOI: 10.5171/2021.865905 
(cf. The article that tracks these aspects of our work: Vrchlabska, Jadrna, and Neubauer, Unpublished).

There are many materials written about students' motivation, from young learners to university students (Parceaud 2013), and if and how intrinsic motivation can influence the results when learning a second language. These questions keep the researchers occupied for a long time (Herzlich, 1978; Noels, Pelletier, Clément and Vallerand, 2000). However, one major group remains unnoticed in the pedagogical research; this group consists of young soldiers who study French. A unique character of our courses, both intensive and short, is that the group is homogenous (all of them are soldiers, in general, young men and French beginners); thus, it opens a possibility to analyze factors of the intrinsic motivation. It could be interesting not only for our future attendees but as well for their superiors. The topic of motivation was very attractive in the context of adult learning, and this subject was scrutinized profoundly from our side.

All the studies mentioned above focus mainly on young learners or teenagers. Our groups are rather specific as they unite adults of a particular profession and a particular length of the courses, generally lasting from two to four weeks. On top of that, their goal is clearly defined - learn French so they can operate effectively in that language abroad.

The phenomena of motivation have been observed from various angles and described in great detail in numerous studies (cf Graham and Weiner 1996). This article is certainly one of a few that tackle this topic more profoundly.

When learning a second language, the aspect of motivation has also been described in many scientific studies (i.e., Parceaud 2013). The term and theory of self-determination are arising persistently when learning a foreign language.

This theory has an advantage over empirically derived frameworks in that it provides psychological mechanism - self-determination and perceived competence - that can explain and predict how orientations are related to learning outcomes (Noëls et al. 2000, p. 7).

Based on the facts mentioned above, the specific study groups and the character of the courses, we stay focused on the phenomena of intrinsic motivation. This type of motivation is an activity linked to itself; for example, a person performing certain tasks can experience positive feelings such as effectiveness or social interchange provided by the task. The intrinsic motivation is also influenced (determined) by the task itself and its attributed value.

Psychologists define intrinsic motivation as a form of motivation with a drop of selfdetermination. The learners enjoy learning and are eager to learn a foreign language voluntarily. The students feel independent and competent enough to keep themselves engaged and endeavored without seeking the necessity of external rewards. The learners perceive their autonomy and their competencies in the acquired language (Parceaud 2013).

Shinya Hori scrutinized the issue of selfdetermination, the most important part of motivation, on a sample of 171 university students of FLE (Francais langue etrangere). This theory postulates that intrinsic motivation rise in each individual when three fundamental needs are met (the need for competence, autonomy, and practical usage). Hori proved that once these requirements are met, the level of selfdetermination grows (Hori 2008).

In the context of surveys already carried out, we need to mention Rivka Herzlich and her work, where she analyzed in great detail intentions for choosing French as a second foreign language among Israeli children. Her comparative study proved that children whose parents come from North Africa were highly motivated to learn French despite their poor results in adaptive tests. This text might seem a bit outdated; however, the detailed research and the methodology are still beneficial and highly appreciated. 
Our questionnaire's goals (objects) focus on attendants' motivation and success when learning French as a second language. The specific questions try to reveal the relationship between the external and internal motivation in the students. The survey equally concentrates on the phenomena which can influence future successful students' rates (the acquired language knowledge before the beginning of the course, the length of the course, and of course, autonomous self-study).

\section{The survey}

Having studied various articles (Herzlich 1978, Hori 2008), we believe that students who are motivated even before a course itself will score better. At the same time, their independent and individual work will enhance their future success. We want to underline that intrinsic motivation plays a crucial role in these distant courses. Distance learning is practically based on autonomous work enhanced by the high motivation of each individual. This distance learning situation reveals strong and weak points of motivation when learning French as a second language. So does learning French at home require accelerated (boost/ intensified) intrinsic motivation?

All the mentioned studies provide a great sample; more than a hundred students. Our courses do not allow us to convey such an extended survey; however, their conclusions lead to our hypothesis. From the beginning of September 2020 to December 2020, our department prepared three intensive two-week courses and one four-week one during the data collection. One week consists of thirty French lessons. In total, we had 27 learners in our courses, and twenty of them filled the questionnaire. This poor participation was caused by the fact that one part of the students was not able to finish the course. The main reasons for this failure lie in their private lives (schools were closed, and some had to educate their children at home) and technical issues (some of them faced technical difficulties that prevented them from finishing the course). As these courses are very intense, one or two days of absence can result in losing a student. Keeping this in mind, we can confirm that all that passed our courses returned the questionnaires filled.

The survey was carried out in the form of a questionnaire as of 1st September (when the courses started at present form); thus, we preferred the questionnaire in paper form even though some online tools would have been more convenient for immediate analysis.

In the first phase of our research, which lasted from September 2020 until the end of the year 2020, we concentrated on the course forms. At this point, we need to mention that French studies were influenced by a difficult situation caused by Covid -19 , and therefore, the rest of the courses had to be moved online from the beginning of October. The fact that all the courses were transferred online could have enhanced participants' motivation.

Working in an online environment, for example, on different learning platforms such as MS Teams or Zoom, bring great benefits but at the same time some risk. The interruption in personal lives is a phenomenon that keeps a lot of specialists busy and a loss of team spirit or difficulties to stay focused at home (cf. Dumas and Rouiller, 2014). Although online teaching, caused by the Covid-19 pandemic, seems like a recent phenomenon, its threats and opportunities have already been described and studied (i.e., Al-Kilidar and Sixsmith 2021) through students' viewpoints.

\section{Survey results and group observation}

During the survey preparation, we approached the problem from three different angles: how much time the learners decided to spend studying French (during the course and their class preparation); the curriculum - grammar, topics, etc., if all of these are adequately understood. And the final question regarding their motivation and their reasons for studying French, their motivation during the course, and their future projects/ plans with French. 
At first, we scrutinized a question about their entrance level of French. Nine students responded they had already had some practical experience from the past, and three of them reported they had attended French classes in different types of high schools. Another six students tried online tools and different applications such as Duolingo, which is quite popular among them.

All of them who responded positively to the previous question tended to work with their own materials; they worked with materials from their grammar schools, looked up videos and topics on the Internet, hired a native speaker when they tried to improve their pronunciation, etc. Thus, the most beneficial approach lies in pre-course work and preparation rather than in almost lost high school knowledge.

Secondly, we studied in detail given topics, grammar, and language functions which they had to acquire. This part of the study is crucial for our future survey, where we would like to compare acquired knowledge with their preparation (work/ studies/ learning)

The next section is predefined by the following question: why have you decided to study French? Nine respondents answered that they had been sent to the course. The rest of them usually ticked these two possibilities - personal interest and other. Thus, we can simplify the reasons into three fields; firstly, they need it for their work; secondly, they want to learn it to better communicate during their duties on missions. Thirdly, this group regroups people who find pleasure in studying languages, and it is their passion.

We cannot forget to mention here that all of them were already advanced users of one or more international languages, mostly English or Russian, Spanish or German.

Most of our interviewees, 13 people, attended a two-week course, another seven participants attended a four-week course. When we compare the motivation in the four-week course, we noticed two combined factors - those who were sent to this course (so their motivation was rather extrinsic) and those with a previous language scholar experience. For a better illustration, typical learners respond that they attended French courses at grammar school or university (never forget to mention they had all forgotten it), they had been sent to the course and didn't use any other materials (e.g., they did not look up extra materials on the Internet). On the other side are those who were unexposed to French at their grammar schools, but they were exposed to this language during their stays in French North Africa and collaborated with online language tools to show higher intrinsic motivation. We compare observation in phase two of our survey to postulate that those who are used to working autonomously show a higher effort to acquire a better language level.

Learners from two-week courses had no previous experience with French learning before the course, so we can compare only their motivation. We can also postulate the fact that those who were motivated intrinsically also showed certain tendencies to work autonomously, meaning they typically used online tools (i.e., Duolingo, even before the beginning of the course) or consulted native speakers.

In our survey, we also tried comparing the relations between ranks and their attitude towards learning French. Our study consisted of one major, four first lieutenants, five warrant officers, and six senior warrant officers; the officers also graduated from university. As per our survey, there is no evidence that university education/ military rank increases motivation level.

We opened this topic based on Hori's study of the relationship between intrinsic motivation and success in learning a second language. She scrutinized the dependence between the satisfaction of basic needs and motivation. We opened this topic based on Hori's study of the relationship between intrinsic motivation and success in learning a second language, where she scrutinized the dependence between the satisfaction of basic needs and motivation. After our 
survey, we can confirm the relationship between autonomous determination and auto evaluation in participants; this phenomenon was even stronger because of distance education.

Rivka Herliz proved in the seventies that the motivation for choosing French as a second language is more important than aptitude tests. We have also observed the same tendency, even though our sample is rather modest. Our interviewees who reported being sent to the course showed weak motivation (they did not work in their free time nor use any online tools); however, the second group was motivated to learn the language.

This part of a study was also described in detail in one of our colleagues' (Rozsypalková, Brzobohatá) work focused on metacognition which could effectively enhance intrinsic motivation for language learning. Although the intrinsic motivation was reported quite high, without an appropriate level of metacognition, the learners were not able to adopt adequate learning strategies and therefore were not able to regulate their own learning process.

Based on the acquired answers, we would like to finish the whole research by a study of whether the students continue learning French after the course. This phase of research is difficult to plan as the students do not know until the last second whether they are to be deployed or not.

\section{Conclusion}

In regards to successful language learning, success lies in the students' motivation. Our study focused on groups of young soldiers who attended French courses that lasted between two and four weeks. After reading studies concerning intrinsic motivation at learners studying a second language, our questionnaire was carried out during the autumn semester of 2020 that was affected by a world's pandemic situation, which underlines the necessity of students' intrinsic motivation.

Our observations prove that students who showed intrinsic motivation even before the start of a respective course (either for personal or professional reasons) tended to work better in their leisure time, plus, they seemed to find alternative routes to learn French, not to mention that previous education in French or work promotion do not play a significant role. We suppose that this high intrinsic motivation allows the learners to acquire French. This will become another phase of our research.

Our subsequent study will also focus on creating an adaptive test on a scale of 0-100 points, consisting of both passive skills: reading and listening. This test will provide us better feedback on how and if the Stanag results correspond with European Framework (CEFR). Last but not least, to study a correlation between intrinsic motivation and final results in the adaptive test as well as in the Stanag exam. The final phase of the research should be planned as a comparative study between acquired Stanag results and a respective adaptive test. Based on these adaptive test results, we could predict a successful rate and probability of how learners will score at the Stanag exam.

\section{References}

- Al-Kilidar, H., and Sixsmith, A. (2021), 'Transition to Online Learning during COVID-19: What do Students Think?' [Online]. Journal of e-Learning and Higher Education. [1.3.2021]. Available: https://ibimapublishing.com/articles / JELHE/2021/919218/

- Brzobohata, H., Rozsypalkova,, J. (2020) What determines progress in language skills development of adult learners in the context of english courses for czech military personnel? EDULEARN20 Proceedings, ISBN: 978-84-09-179794, 6-7 July, 2020, Online Conference, 8949-8953.

- Dumas, M., and Ruiller, C. (2014), 'Le télétravail : les risques d'un outil de gestion des frontières entre vie personnelle et vie professionnelle ?' Management Avenir, (8), 71-95.

- Graham, S., and Weiner, B. (1996), 'Theories and principles of motivation.' https://chine.in/fun/signechinois. 
Handbook of educational psychology, 4(1), 63-84.

- Herzlich, R. (1978), 'L'attitude et la motivation des élèves israéliens dans l'apprentissage du français, seconde langue étrangère.' International Review of Education, 24(4), 467-481.

- Hori, S. (2008), 'Application de la theorie de l'autodetermination à l'enseignement du FLE : corrélation entre le degré d'autodétermination et la performance.' Revue japonaise de didactique du français, 3(1), 84-99.

- $\quad$ Noels, K. A., Pelletier, L. G., Clément, R., and Vallerand, R. J. (2000), 'Why are you learning a second language? Motivational orientations and self- determination theory. ' Language learning, 50(1), 57-85.

- Parceaud, C. (2013), 'Niveaux de motivation (amotivation, extrinsèque, intrinsèque) et orientation (instrumentale et intégrative) en anglais, langue seconde chez des collégiens au Cégep de Rimouski' (Doctoral dissertation, Université du Québec à Rimouski).

- Vrchlabska, Y., Jadrna, J. Neubauer, J. (2020), 'Quand la Recherche de Qualité dans l'Enseignement Passe par une Etude Statistique entre les Langues Anglaise et Française' 36th IBIMA, ISBN: $\quad$ 978-0-9998551-5-7. 4-5 November 2020, Cordoba, Spain. 